\title{
BUDDHIST TEXTS IN SANSKRIT FROM TAMIL NADU
}

\author{
Lavanya V Eswar
}

\begin{abstract}
Buddhism reached South India and Ceylon at the time of Asoka from the north and thus began to spread gradually. Variuos centres of Buddhist religion were established in south India even in the early Christian era. Buddhism continued to exist in the Tamil land till about the 13th century. But the golden age was from 2nd to 8th century A.D. as known from Tamil, Pali and Sanskrit works. Several Buddhist scholars also went from South India to North India, Ceylon and China and wrote treatises on Buddhism or translated imporatnt Buddhist works. Renowned scholars like Āryadeva, Candrakīrti, Dinnāga and Dharmakīrti reigned supreme during this period.

This paper shall deal with a few of the early writers of Buddhist works in Sanskrit associated with Tamil Nadu.
\end{abstract}

The earliest and most revered Buddhist monk is Āryadeva, also called Deva, Kāṇadeva and Nīlanetra. Huen Tsang regarded him along with Nāgārjuna, Aśvaghoṣa and Kumāralabdha as "one of the four suns which illuminated the world". Traditional biographies accept him as a student and successor in the Mādhyamaka lineage. He belonged to the first half of the third century A.D.

Āryadeva occupies an important position, next only to Nāgārjuna, in the history of Buddhist philosophical thought and its exposition. He is known to have authored nearly forty major and minor works in Sanskrit, though most of them are available only in their Tibetan and Chinese versions. Of his four philosophical writings, the Catușśataka is of great imporatnce. It is also called Bodhisattvayogācāra and Vaipulya Śataśāstra. It is in sixteen chapters, each of them having $25 k \bar{a} r i k \bar{a} s$ in 
32 syllabled Anuștubh or Śloka metre.It is mainly concerned with the disciplined conduct (yogācaryā) of a Bodhisattva.

Āryadeva's Śataśāstra and Akșara Śataka are similar to Catuhśataka. There are slight differences in the arrangement of the toipcs and the arguments against the opponents. His works are noteworthy for their literary value also. He puts across his philosophical ideas in an interesting and direct manner.

Buddhaghoșa, a well known figure in the field of Buddhism is known to have flourished in the first half of the fifth century A.D. He is considered to belong to Andhra and probably spent most of his early life in South India. He wrote commentaries on the Tripititika. His work Padyacūdāmani is a mahākāoya in Sanskrit in ten sargas and nearly 640 verses. This poem narrates in the classical style the birth, sad events and the ascetic life of prince Siddhartha.

Dinnāga (Dignāga) was the famous Buddhist logician of the 5 th to 6 th century A.D. He belonged to the Simmavatharam village near Kañcīpuram. He became a disciple of Vasubandhu and learnt all the Mahāyāna doctrines from him. He was a younger contemporary of Bhatṛhari whose thirty Kārikas in Vākyapadīya (III 3.55-85) are adopted by him in his work Trikāla-(Traikalya)- parīkșa, a polemic against Brahminism. Several works, major and minor, are ascribed to him but the Sanskrit originals of most of them are lost. He is regarded as "the father of the medieval Nyāya and the link between the Buddhist orthodox Nyāya systems of India". His Prajñāpāramitāpindērtha Sangraha in fifty eight verses gives a summary of Wisdom-Perfection according to the Yogācāra standpoint. Yogāvatāra in nine verses deals succinctly with the concept of ultimate reality according to the Yogācāra school. His other works are the Nyāyapraveśa, $\bar{A}$ lambana-parīkșā and Pramānasamuccaya. His authentic logical ideas and method of exposition are referred to in varied treatises including Sanskrit aesthetic texts like Dhvanyāloka and its commentary Locanā.

Candrakīrti, a student of Kamalaśuddhi and Dharmapāla, belonged to the 6th-7th centuries. The Mādhyamika system taught by Nāgārjuna and Āryadeva, found in him a masterly exponent and systematiser. His Prasannapada ('clearly worded') is the only Sanskrit commentary on Mādhyamaka Kārikās. Moreover, his commentary on the Catuhśataka makes the metaphysics of Āryadeva more interesting and enjoyable through his apt comparisons and maxims. Besides the above two commentaries, he wrote other scholarly commentaries and 
independent works like-Catuhśatakavṛtti, Yuktiśaștikavṛtti, Śn̄nyatāsaptavrtti, Mādhyamakāvatāra with his own commentary, Pañcaskandhaprakarana, Mādhyamakaprajñāvatāra.

Dharmapāla (540-610 A.D.) wrote a commentary on Vijñāptimātratāsiddhi of Vasubandhu was transalted into Chinese. He was Chief Professor at Nalanda and is asid to be a contemporary of Bhāvaviveka and Bhartṛhari.

Dharmakīrti was another great philosopher, an eminent poet and a logician of the 7th century. His teachers were Isvarasena and Dharmapāla. He wrote the following works- Pramānavārttika, Pramānavinicchaya, Nyāyabindu, Hetubindu, Sambandhaparīkșa, $V \bar{a}$ danyāya, and Santānantarasiddhi. His great classic in logic is the Pramānavārttika, a commentary and supplement to Dinnāga's Pramānasamuccaya. He also wrote commentaries, on the first chapter of Pramānavārttika and on Sambandhaparīkșa. Dharmakīrti was also a poet and the anthologies like the Sūktimuktāvali of Śrīdharadāsa and Jalhana and the Subhasșitāvali of Vallabhadeva quote his verses. Ānandavardhana, while elaborating on - lāvanyadravinavyayo na ganitah ... (on Kārikā 40) which is an instance of Aprastutapraśamsā, refers to Dharmakīrti as a pessimistic poet .

Anuruddha Thera was another Buddhist Sanskrit and Pali writer of 12 th century who lived at Kāñì. Among his works, the Anuruddhaśataka and Nāmarūpapariccheda may be mentioned.

Thus it can be seen from the above that all these scholars happily combined in themselves mastery in logic and other sciences with the felicity of poetic style and capacity to write lyrical verses. According to Bhāmaha, a 6th century Alañkāra writer, poetry and science (Ś̄astra) went hand in hand, and were never antogonistic to each other.

\section{Biblography :}

1. Buddhism in Tamil Nadu, Institute of Asian Studies, Chemmancherry, Chennai, 1998

2. Contribution of Tamil Nadu to Sanskrit by Dr. C.S. Sundaram, Institute of Asian Studies, Chemmancherry, Chennai, 1999

3. Dhvanyāloka of Ānandavardhana, ed. by Dr. K. Krishnamoorthy, Motilal Banarasidass, Delhi, 1974.

4. Story of Buddhism with special reference to South India by A.Aiyappan and P.R.Srinivasan, Department of Information and Publicity, Government of Madras, 1960 